\title{
WEIGHT ADDITION ON PREGNANT WOMEN AS A QUALITY PREDICTOR OF FAMILY DAILY FOOD CONSUMPTION PATTERN
}

\author{
Awatiful Azza ${ }^{*}$, Cipto Susilo ${ }^{2}$ \\ Faculty of Health Sciences University of Muhammadiyah Jember \\ Email* : awatiful.azza@unmuhjember.ac.id
}

\begin{abstract}
Introduction: Pregnancy is a physiological condition experienced by women after marriage. Physical changes and development occur in pregnant women can determine the health conditions of the mother and fetus. Nutritional status of the mother is one of an important key factors in pregnancy. The objective of this study determines the relationship between daily nutritional consumption of family and weight addition on pregnant. Methods: The design used in this study is correlational with cross sectional approach and the data obtained through questionnaires and documentary studies. Data analysis was carried out either quantitatively using Spearman rank or qualitative to deepen the findings in the field. Results: The results of this study found that the $P$-value 0.002 which means there is a relationship between the nutritional consumption with the nutritional status of pregnant women. The correlation coefficient was 0.309 which means a moderate relationship with positive correlation value implied that the better daily nutritional consumption of family, the higher nutritional status of pregnant women. Conclusions: Understanding the nutritional needs of pregnant women requires good cooperation between family and health workers.
\end{abstract}

Keywords : family daily nutrient; nutritional status; pregnancy

\section{INTRODUCTION}

Nutrition is one of the principal determinants of the quality of human resources (Adriani, Merryana dan Wirjatmadi, 2012) (Baliwati dkk., 2004) (Gambling, 2010). The nutrition of pregnant women can be one indicator to measure the nutritional status of the community (Penelitian and Pengembangan, 2013) (Syari, Serudji, 2015). Pregnant women need good-quality nutrition to support their pregnancy so they do not give birth with low birth weight baby (Ariani, 2010) (Kulkarni et al., 2010). Low nutritional status and incorrect eating patterns during pregnancy can lead to anemia, lack of calorie energy, and cause fetal growth impairment (Bakhtiar, Khan and Nasar, 2007) (Syari, Serudji, 2015).

Issues in nutrition is still a major public health problem in developing countries including Indonesia and is an indirect cause of preventable maternal and child mortality actually (Penelitian and Pengembangan, 2013) (Statistics, no date) (RI, 2014). The maternal mortality rate is one indicator of the health status of a country (Kemenkes, 2015). Global data on maternal mortality rates shows that around 830 women die per day due to complications of pregnancy or childbirth so that by 2015 , the estimation of women die during and after pregnancy and childbirth around
303,000 while the data on the ratio of maternal mortality in developing and developed countries in 2015 was 239 per 100,000 live births compared to 12 per 100,000 live births. In Indonesia, the case of maternal and newborn mortality according to the evaluation of the Millennium Development Goals (MDGs) program in 2013, is still at 305 per 100,000 births (Knudsen et al., 2008) (Bakhtiar, Khan and Nasar, 2007). This condition can actually be prevented if the mother gets enough nutrition for herself and for the development of the fetus during pregnancy (Kulkarni et al., 2010).

Anemia is one of the complications of pregnancy that can threaten the lives of pregnant women and their babies as well as can increase the risk of born prematurely and low birth weight babies (Bakhtiar, Khan and Nasar, 2007) (Kulkarni et al., 2010). The mother needs to pay attention to the food consumed during pregnancy, so they can give birth to healthy children (Knudsen et al., 2008). Food consumed must be adjusted to the needs of the body and the fetus because, during pregnancy, the food consumed is not only to provide for the mother's need but also the fetus (Endeshaw et al., 2014) (Marangoni et al., 2016). The amount of food consumed also needs to be increased but must be adjusted to the needs of the fetus to avoid overweight during pregnancy (Syari, 
Table 1: Characteristics of respondents based on age, gestational age, height, and body mass index before pregnancy

$\quad$ Variables
Mother's age
15-25 years of age
$26-35$ years of age
$>35$ years of age
n
Gestational age
$4-6$ months
$7-9$ months
n
Mother's height
$<150 \mathrm{~cm}$
$150-155 \mathrm{~cm}$
$>155 \mathrm{~cm}$
n
Body Mass Index before pregnar
underweight
Normal weight
Overweight
n
Complaints during Pregnancy
Nausea
No weight gain
Dizziness
n

Serudji, 2015) (Hamid, Setiawan and Suhartini, 2013).

Intake of nutrition determines the health status of pregnant women and their fetus. Compared to normal women condition, nutritional needs during pregnancy increase 15\% (Syari, Serudji, 2015) (Knudsen et al., 2008). The enhancement of nutritional needs is important for some conditions like the growth of the uterus, breasts (mammae), blood volume, placenta, amniotic fluid, and fetal growth (Wu et al., 2004). Food consumed by pregnant women will be used for fetal growth by $40 \%$ and $60 \%$ remaining is used for the mother $(\mathrm{Wu}$ et al., 2004). Normally, the weight of pregnant women will gain by 11-13 kilograms since the need for food intake for pregnant women increases in line with gestational age (Marangoni et al., 2016). Early identification of the nutritional status of pregnant women is very important to prevent complications in pregnancy due to malnutrition both macro and micronutrients (Knudsen et al., 2008) (Marangoni et al., 2016). There are several monitoring methods of the nutritional status of

$\begin{array}{cc}\text { F } & \text { Percentage (\%) } \\ & \\ 12 & 12 \\ 67 & 67 \\ 21 & 21 \\ 100 & 100 \\ & \\ 67 & 67 \\ 33 & 33 \\ 100 & 100 \\ & \\ 24 & 24 \\ 48 & 48 \\ 38 & 38 \\ 100 & 100 \\ & \\ 28 & 28 \\ 65 & 65 \\ 7 & 7 \\ 100 & 100 \\ & \\ 68 & 68 \\ 17 & 17 \\ 25 & 25 \\ 100 & 100\end{array}$

pregnant women such as monitor weight gain during pregnancy, the height of uterine fundus, measuring the circumference of the upper arm, and also hemoglobin levels since the measurement of hemoglobin levels in pregnant women is the simplest way to determine their nutritional status (Knudsen et al., 2008) (Schoenaker, Soedamah-Muthu and Mishra, 2014). Hemoglobin levels in pregnant women and nutritional intake during pregnancy will always be in parallel. Insufficient nutritional intake during pregnancy can cause low levels of hemoglobin which can lead to anemia (Endeshaw et al., 2014).

Energy requirement for pregnant women increases around 80,000 kcal above the daily consumption before pregnancy and it means there is an increase of $300 \mathrm{kcal}$ every day during pregnancy (Schoenaker, Soedamah-Muthu and Mishra, 2014). The Public Health Agency of Canada suggests several dietary recommendations to help pregnant women to provide their increased calorie and nutritional needs (Ariani, 2010) (Schoenaker, SoedamahMuthu and Mishra, 2014) (Mecacci et al., 
Table 2: Characteristics of respondents based on education, occupation of husband, and mother's daily activity

\begin{tabular}{lcc}
\multicolumn{1}{c}{ Variables } & F & Percentage (\%) \\
Education & & \\
Elementary School & 27 & 27 \\
Junior High School & 49 & 49 \\
Senior High School & 23 & 23 \\
College / University & 1 & 1 \\
n & 100 & 100 \\
Occupation of husband & & \\
Government Employees & 1 & 1 \\
Entrepreneur & 31 & 31 \\
Labor & 48 & 48 \\
Unemployees & 20 & 20 \\
n & 100 & 100 \\
Mother's daily activity & & \\
Mild & 41 & 41 \\
Moderate & 38 & 38 \\
High & 21 & 21 \\
n & 100 & 100
\end{tabular}

Table 3: Analysis of weight gain of pregnant women through providing the nutritional needs of the family

\begin{tabular}{|c|c|c|c|}
\hline & & $\begin{array}{l}\text { Providing the nutritional } \\
\text { needs of the family }\end{array}$ & $\begin{array}{l}\text { Weight gain of } \\
\text { pregnant women }\end{array}$ \\
\hline \multirow{3}{*}{$\begin{array}{l}\text { Providing the nutritional } \\
\text { needs of the family }\end{array}$} & $\begin{array}{l}\text { Pearson } \\
\text { Correlation }\end{array}$ & 1 & $0.309^{* *}$ \\
\hline & Sig. (2-tailed) & & 0.002 \\
\hline & $\mathrm{N}$ & 100 & 100 \\
\hline \multirow{3}{*}{$\begin{array}{l}\text { Weight gain of pregnant } \\
\text { women }\end{array}$} & $\begin{array}{l}\text { Pearson } \\
\text { Correlation }\end{array}$ & $0.309^{* *}$ & 1 \\
\hline & Sig. (2-tailed) & 0.002 & \\
\hline & $\mathrm{N}$ & 100 & 100 \\
\hline
\end{tabular}

2015). Additional recommendations include increasing water intake and avoid food transmission diseases from undercooked fish and meat, raw eggs, unpasteurized products, and raw sprouts (Syari, Serudji, 2015) (Hamid, Setiawan and Suhartini, 2013).

This study aims to conduct an analysis of the weight gain of pregnant women associated with the quality of daily family food consumption patterns with a focus on analyzing the daily eating habits of a family with pregnant women.

\section{METHODS}

This study used cross-sectional data analysis involving pregnant women in the District of Jember with a retrospective study of 100 pregnant women. Sampling technique was performed using a purposive method in accordance with the inclusion criteria, the second and third trimesters pregnant women who did not have chronic diseases. Data collection was performed using a questionnaire about the daily food consumption pattern of the family which is a modification from semiquantitative food frequency questionnaire (SQFFQ) to assess the history of family eating habits for the past 3 months. Identification of 
the weight was measured using a scale, then the results are carried out using a basal mass index to categorize the weight of pregnant women.

Demographic data was collected through a questionnaire including age, education, occupation, weight before pregnancy, height, and the number of family members. Data about the family's daily food consumption pattern is collected through a questionnaire while data about weight gain is done by weighing.

Univariate analysis was performed on demographic data and each variable in this study while non-parametric test with the Spearman rank was performed to identify the relationship between family daily food consumption habits with an increase in the weight of pregnant women.

Ethical approval was obtained from the Research Ethics Committee at the Faculty of Health Sciences University of Muhammadiyah Jember.

\section{RESULTS}

\section{Demographic Data}

The results of the tabulation in Table 1 shows that pregnant women are in the productive age range, between 26-35 years of age with most of the gestational age in the second trimester. According to the nutritional status before pregnancy, mostly have a normal category of body mass index.

Table 2 shows that most respondents have junior high school education with their husband work as labor, whereas the mother's daily activity categorized as mild.

Based on the analysis with spearmen Rho (Table 3), it was found that the P-value 0.002 which means there is a relationship between providing the nutritional needs of the family with a weight gain of the mother during pregnancy. The correlation coefficient was 0.309 which means a moderate relationship with positive correlation value implied that the better daily nutritional consumption of the family, the higher nutritional status of pregnant women.

\section{DISCUSSIONS}

The nutritional status of pregnant women is a main priority that must be fulfilled by the family in order to mothers are able to deliver healthy babies (Symington et al., 2018) (Wu et al., 2004). Many factors affect the nutritional status of pregnant women including their low education. Mother's education can be an indicator of the mothers' level of understanding in managing their nutrition during pregnancy (Hamid, Setiawan and Suhartini, 2013). This is supported by the result of this study shows that most respondents have junior high school education (49\%) which implied that this condition causes the mother to be less creative with staple foods.

Data about the main source of carbohydrates to provide the needs of the mother's macronutrients is rice even though many other carbohydrate sources can be processed into a staple food (Syari, Serudji, 2015). The importance of a mother's education is also stated in the Nutrition Surveillance System (NSS) data assessment which shows that education level indicators can be used as proxies for socioeconomic level indicators of the family and smarter family parenting (Symington et al., 2018). Educated pregnant women will be smarter in managing household resources and the higher their bargaining position as well (Kulkarni et al., 2010). The issue of nutrition on pregnant women has broad implications, both for the mother and fetus. Riyadi (2003) stated that in general, the higher level of education and nutritional knowledge the higher the awareness to provide a balanced consumption pattern, fulfill nutritional requirements and selective regarding food security (Hamid, Setiawan and Suhartini, 2013). Food consumption pattern depends on education in a family (Hamid, Setiawan and Suhartini, 2013). The higher the formal education of the community, the knowledge about the importance of good quality food consumption to improve health status will increase varied food consumed and nutritional and health needs that are expected to be better (Rahmawati, 2017). Knowledge also influences food in the culture of society, for example, Javanese have better knowledge to consume local food such as tubers (Suhardjo, 2008) (Syari, Serudji, 2015).

Anemia is a condition due to lack of nutrition (Bakhtiar, Khan and Nasar, 2007) (Marangoni et al., 2016). Several studies showed a close correlation between anemia during pregnancy and fetal death, misbirth/abortus, a congenital defect, low birth weight babies, poor iron reserves in children, and born in a state of nutritional anemia (Syari, Serudji, 2015). This condition causes the elevation of perinatal mortality rate including 
maternal mortality and morbidity (Symington et al., 2018) (Marangoni et al., 2016). The result of this study showed that $\mathrm{P}$-value 0.002 which means there is a relationship between providing the nutritional needs of the family with a weight gain of the mother during pregnancy. The correlation coefficient was 0.309 which means a moderate relationship with positive correlation value implied that the better daily nutritional consumption of the family, the higher nutritional status of pregnant women. There are several factors that affect daily food consumption such as (1) food supply, (2) household income, (3) knowledge about nutrition, and (4) number of household members. Local culture and preferences also influence the type and amount of food consumed. Fulfillment of good family food must contain staple foods, side dishes, fruits and vegetables, and consumed in sufficient quantities as needed. Good dietary pattern and variety of dishes can guarantee the fulfillment the adequacy of energy sources so that the nutritional status will be better and strengthen the immune system to fight the disease (Baliwati dkk., 2004).

Pregnant women must pay attention to their nutritional status since the nutritional status of the mother before and during pregnancy can affect the growth of the fetus (Knudsen et al., 2008). Mothers with normal nutritional status before and during pregnancy will give birth to a healthy baby with a normal weight (Symington et al., 2018). Most nutritional problems are caused by low consumption of energy and other nutrients during pregnancy (Schoenaker, SoedamahMuthu and Mishra, 2014). Several factors that can influence food consumption are food availability at the family level, consumption patterns, education level, and mother's knowledge (Syari, Serudji, 2015) (Awatiful Azza 1, 2014). In this study, $48 \%$ of husband's respondents work as labor. This fact can certainly affect the socio economic of the family in providing good nutrition to pregnant women (Kulkarni et al., 2010). Energy intake and quality of life are strengthened by protein intake. Energy will increase in line with protein intake (Agueh et al., 2015) (Syari, Serudji, 2015). The combination of decreased nutritional status with nutritional deficiencies is a more important factor in predicting the weight of pregnant women. Decreased nutrient reserves can affect the growth and development of maternal pregnancy (Syari, Serudji, 2015) (Bakhtiar, Khan and Nasar, 2007) (Gambling, 2010).

\section{CONCLUSIONS}

The results of this study indicate that pregnant women experience nausea, especially in the first trimester of pregnancy which affects changes in body weight. Also, this study shows that mothers tend to consume rice as a staple food for main source of macronutrients, there is no modification of other carbohydrate sources in their daily menus, while the results of the correlational analysis found that the family daily food consumption pattern is associated with weight gain during pregnancy.

\section{SUGGESTIONS}

Improvement program for the quality of nutrition consumption of pregnant women through counseling and diversification of staple foods need to conduct regularly by introducing variations in other carbohydrate sources so that they do not only consume rice as the main food but also modify another carbohydrate sources such as sweet potatoes and corn. In addition, collaboration with program holders on health services is needed in order to monitor the growth and development of pregnant women.

\section{REFERENCES}

Adriani, Merryana dan Wirjatmadi, B. (2012) Pengantar Gizi Masyarakat.

Agueh, V. D. et al. (2015) 'Dietary Calcium Intake and Associated Factors among Pregnant Women in Southern Benin in 2014', (August), pp. 945-954. doi: 10.4236/fns.2015.611098.

Ariani, M. (2010) 'Analisis Konsumsi Pangan Tingkat Masyarkat Mendukung Pencapaian Diversifikasi Pangan', Gizi Indonesia, 33(1), pp. 20-28.

$\begin{array}{llr}\text { Awatiful Azza 1, C. S. (2014) 'THE } \\ \text { LEARNING } & \text { MODEL } & \text { OF } \\ \text { REPRODUCTIVE } & \text { HEALTH } \\ \text { THROUGH A PEER GROUP WITH } \\ \text { A CULTURE OF } & \text { EARLY } \\ \text { MARRIAGE } & \text { IN } & \text { THE } \\ \text { TRADITIONAL } & \text { BOARDING } \\ \text { SCHOOL, JEMBER', in Building } \\ \text { Transcultural Nursing in Education } \\ \text { and Practice to Facing Asean } \\ \text { Community } & \text { 2015. Bandung: }\end{array}$


AIPNEMA, pp. 15-28.

Bakhtiar, U. J., Khan, Y. and Nasar, R. (2007) 'Relationship between maternal hemoglobin and Perinatal outcome'.

Baliwati dkk. (2004) Pengantar Pangan dan Gizi. Jakarta: Penebar Swadaya.

Endeshaw, M. et al. (2014) 'Effect of maternal nutrition and dietary habits on preeclampsia: a case control study', International Journal of clinical Medicine, (December), pp. 14051416. doi: 10.4236/ijcm.2014.521179.

Gambling, M. A. (2010) Nutrition requirment during pregnancy chapter I. Cambridge: United Kingdom University Press.

Hamid, Y., Setiawan, B. and Suhartini (2013) 'Analisis pola konsumsi pangan rumah tangga (Studi kasus di Kecamatan Tarakan Barat Kota Tarakan Provinsi Kalimantan Timur)', Agrise, 13(3), pp. 175-190.

Kemenkes (2015) INFO DATIN, Pusat Data Dan Informasi Kementrian Kesehatan RI.

Knudsen, V. K. et al. (2008) 'Major dietary patterns in pregnancy and fetal growth', European Journal of Clinical Nutrition, 62(4), pp. 463470. doi: 10.1038/sj.ejcn.1602745.

Kulkarni, B. et al. (2010) 'Determinants of compliance to antenatal micronutrient supplementation and women's perceptions of supplement use in rural Nepal', Public Health Nutr, 13(1), pp. 82-90. doi: $10.1017 / \mathrm{s} 1368980009005862$.

Marangoni, F. et al. (2016) 'Maternal diet and nutrient requirements in pregnancy and breastfeeding. An Italian consensus document', Nutrients, 8(10), pp. 1-17. doi: $10.3390 /$ nu8100629.

Mecacci, F. et al. (2015) 'Nutrition in pregnancy and lactation: how a healthy infant is born', Jpnim, 4(2), pp. 1-14. doi: 10.7363/040236.
Penelitian, B. and Pengembangan, D. A. N. (2013) 'RISET KESEHATAN DASAR'.

Rahmawati, A. (2017) 'Pengambilan Keputusan Dalam Pemilihan Pangan Lokal Olahan dan Pola Konsumsi Pangan Rumah Tangga Sekitar Agroindustri Bihun Tapioka di Kota Metro', Penelitian tidak dipublikasi.

RI, K. (2014) Pusat Data dan Informasi Kementerian Kesehatan RI. Kementerian Kesehatan RI.

Schoenaker, D., Soedamah-Muthu, S. S. and Mishra, G. D. (2014) 'The association between dietary factors and gestational hypertension and preeclampsia: a systematic review and meta-analysis of observational studies.', BMC medicine, 12(1), p. 157. doi: 10.1186/s12916-014-01577.

Statistics, H. (no date) Profil Kesehatan Indonesia 2012. Jakarta: Kementerian Kesehatan. Pusat Data dan Informasi Profi Kesehatan Indonesia.

Suhardjo (2008) Perencanaan Pangan dan Gizi. Jakarta: Bumi Aksara.

Syari, Serudji, \& M. (2015) 'Peran Asupan Zat Gizi Makronutrien Ibu Hamil terhadap Berat Badan Lahir Bayi di Kota Padang', Jurnal Kesehatan Andalas, 4(3), pp. 729-736. doi: 10.3975/cagsb.2015.05.08.

Symington, E. A. et al. (2018) 'Nutrition during pregnancy and early development (NuPED) in urban South Africa: A study protocol for a prospective cohort', BMC Pregnancy and Childbirth. BMC Pregnancy and Childbirth, 18(1), pp. 1-12. doi: 10.1186/s12884-018-1943-6.

$\mathrm{Wu}, \mathrm{G}$. et al. (2004) 'Recent Advances in Nutritional Sciences Maternal Nutrition and Fetal', The Journal of Nutririon, (13), pp. 2169-2172. Available at: http://jn.nutrition.org/content/134/9/2 169.full.pdf. 